\title{
Arduino fejlesztői platformmal vezérelt pontmátrix nyomtató
}

\author{
Barkaszi Ádám \\ Debreceni Egyetem, \\ Informatika Kar \\ Debrecen, Magyarország \\ barkaszi.adam@gmail.com
}

\author{
Beatrix Papp \\ London South Bank \\ University \\ School of Law and Social \\ Sciences, \\ London, United Kingdom \\ pappb@1sbu.ac.uk
}

\author{
Erdei Timotei István \\ Mechatronikai Tanszék \\ Debreceni Egyetem, Müszaki Kar \\ Debrecen, Magyarország \\ timoteierdei@eng.unideb.hu
}

\begin{abstract}
Absztrakt - Napjainkban egyre nagyobb teret hódít az újrahasznosítás. A környezet megóvásában fontos szerepet játszik az anyagok és eszközök újra felhasználása, feldolgozása. Gazdaságossági szempontok is indokolják, hogy a már nem üzemképes eszközöket, vagy azok alkatrészeit felhasználva új, müködőképes tárgyakat, gépeket hozzunk létre. Ezeket szem előtt tartva került megvalósításra a projekt. A használaton kívüli CD/DVD olvasó, illetve régi nyomtató alkatrészeinek felhasználásával.
\end{abstract}

Kulcsszavak-Arduino; nyomtató; motor vezérlés, meghajtók, újrahasznosítás

\section{BEVEZETÖ}

Kínában már a VIII. században használták, Európában azonban csak a reneszánsz-korban kezdték alkalmazni a dokumentumok sokszorosítására használt nyomtatást. Az erre használt nyomtatók a napjainkig számos változáson estek át. Több fajtája jelent meg, más-más technológiát használva. A tintasugaras és lézer nyomtatók használatával jobb minőség érhető el, ha viszont az alacsonyabb nyomtatási költség a fontos, akkor a mátrix nyomtató alkalmazása célszerü [6].

A projekt vezérlésének alapját az Arduino fejlesztői platform egyik modellje, az Uno adja. 2005-ben, Olaszországban Massimo Banzi és Casey Reas alkotta meg a nyílt forráskódú platformot, ami egy mikrokontrollerből, és az annak programozásához használható integrált fejlesztői környezetből áll [1].

Alacsony ára, Open-Source minősítése és könnyü programozhatósága miatt az egyik legnépszerübb mikro vezérlö napjainkban. Az Arduino típusok két nagy csoportra oszthatók. A fö fejlesztő panelek mellett különböző kiegészítő, bővítő lapok, az úgynevezett Shield-ek szerepelnek a kínálatban.

Hátrányként megemlíthető, hogy a programozásához mindenképp szükség van egy számítógéphez, melynek segítségével, USB kábellel tölthetjük fel az eszközre a megírt sketch programot.
A birtokunkban lévő „Dot Matrxi” nyomtató egy Epson T1000 modell volt, ami a 2000 -es évek elején volt alkalmazva [7].

A pontmátrix-nyomtató mechanikai részegységei kerültek felhasználásra a CD/DVD olvasó alkatrészei mellett, úgymint papír továbbító és a nyomtatáshoz használt toll mozgatásához szükséges fogaskerekek és motorok. A kutatás/fejlesztésnek a Debreceni Egyetem adott otthont [9].

\section{TERVEZÉSI SZEMPONTOK}

A nyomtató megtervezésénél elsődleges szempontot az újrahasznosítás, a költségek minimalizálása jelentette.

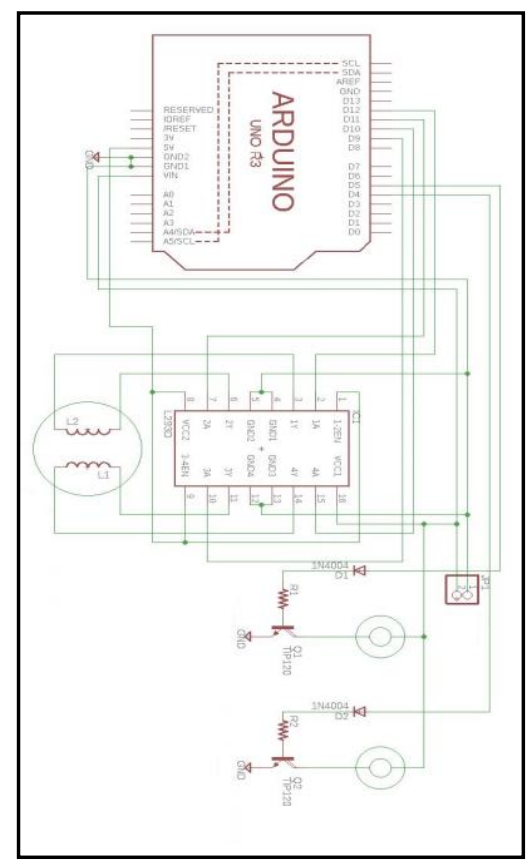

1. ábra A megtervezett áramkör 
A „szán” és a léptető motor vezérlését (oldal irányú mozgás) egy Arduino Uno [2] mikrokontroller és egy L239D [3] jelű motorvezérlő végzi, míg a DC motorokét $2 \mathrm{db}$ 1N4001 dióda, $2 \mathrm{db}$ TIP120 tranzisztor és $2 \mathrm{db} 2,2 \mathrm{k} \Omega$-os ellenállásból álló áramkör. A fent említett alkatrésze látható az 1. ábrán.

A papír továbbító szerkezet a CD/DVD olvasó és tintasugaras nyomtató alkatrészeiből készült. Ugyanígy a toll fel-le mozgató mechanika is, de itt az olvasó komplett tálcakiadó szerkezete is felhasználásra került átalakítással.

Az 1A-es, 7 V-os áramforrást egy szabályozható $(3 \mathrm{~V}-$ $12 \mathrm{~V}$ ) egyenáramú adapter biztosítja.

\section{A MECHANIKAI RÉSZ FELÉPÍTÉSE}

A pontmátrix nyomtató alapját $2 \mathrm{~mm}$ vastag polikarbonát lap, $5 \mathrm{~mm}$ vastag rétegelt lemezre erősítve - a megfelelö stabilitás érdekében - adja. Azért esett a választás erre az anyagra, mert ennek felületén könnyen csúszik a papír, amit az alapra illesztett vonalzópár segítségével vezeti a megfelelö irányba. Erre az alapra kerültek a motorokat és fogaskerekeket tartó, szintén $2 \mathrm{~mm}$ vastagságú elemek. A furatok úgy lettek kialakítva, hogy a toll és a papír mozgatása könnyen mozgatható legyen. Arról, hogy a toll a kezdő állásába térjen vissza, egy pár rugó gondoskodik, ahogyan azok a 2. ábrán jól láthatóak.

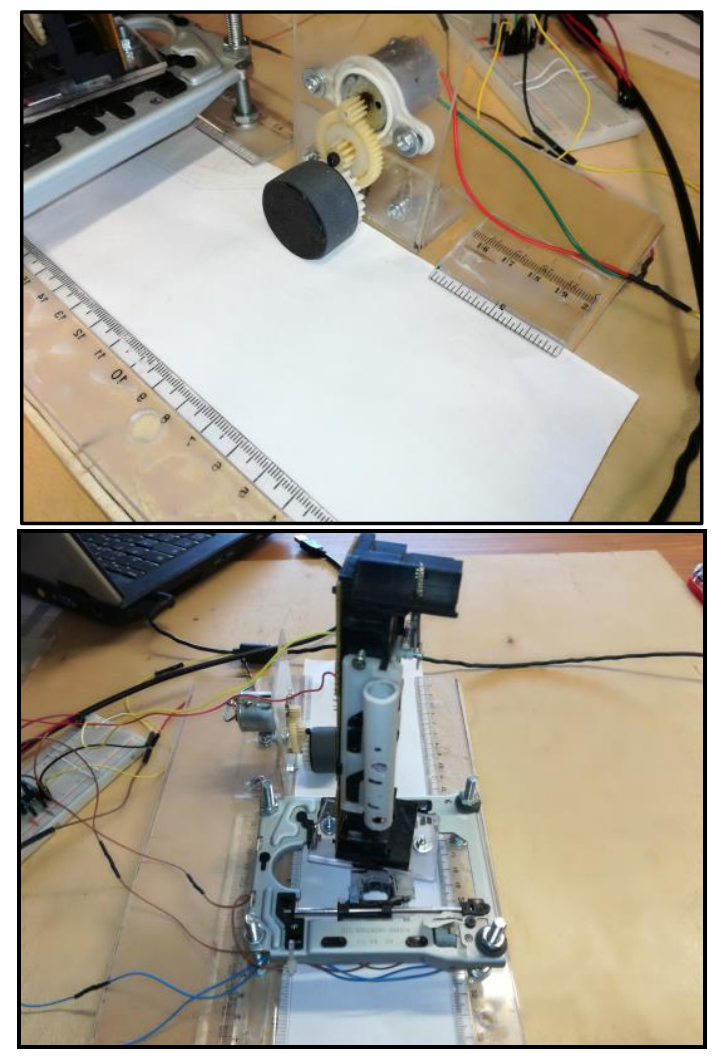

2. ábra A papírt mozgató motor és gumikerék \& toll mozgatását végző egység

\section{MEGÉPÍTETT ÁRAMKÖR}

Az áramkör Fritzing-ben [4] került megtervezésre, ami tartalmazza beépülő modulként az Arduino UNO mikrokontrollert. Ez vezérli a H-hidat tartalmazó L293D motorvezérlő segítségével a bipoláris léptető motort, illetve a TIP120 bipoláris Darlington tranzisztorokon keresztül a másik két motort.

Az 1. táblázatban látható módon került összekapcsolásra az Arduino UNO mikrokontroller, valamint az L293D motorvezérlő.

\begin{tabular}{|c|c|}
\hline \multicolumn{2}{|c|}{ TÁBLÁZAT I. CSATLAKOZÁSI PONTOK } \\
\hline Arduino & L293D \\
\hline D9 & $3 \mathrm{~A}$ \\
\hline D10 & $4 \mathrm{~A}$ \\
\hline D11 & $2 \mathrm{~A}$ \\
\hline D12 & $1 \mathrm{~A}$ \\
\hline $5 \mathrm{~V}$ & VCC2, 1-2EN, 3-4EN \\
\hline GND1, GND2 & GND1, GND2, GND3, GND4 \\
\hline VIN & VCC1 \\
\hline
\end{tabular}

Mivel az Arduino maximálisan 5V feszültséget tud biztosítani az áramkör számára, ezért a $7 \mathrm{~V}$-ot igénylő motorok feszültség igényét egy külső tápforrás látja el.

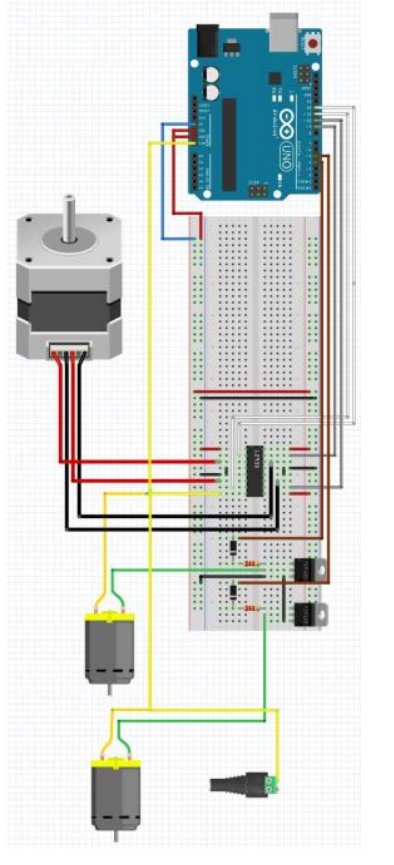

3. ábra : Megtervezett fizikai kapcsolás

A megépített áramkör egy próbapanelre lett felépítve. Amihez az alkalmazott csatlakozóval ellátott jumper vezetékek kerültek felhasználásra. Ennek köszönhetően egyegy hiba könnyebben kijavítható, mivel nincs szükség forrasztásra. Kivételt képeznek ez alól a CD/DVD olvasóból 
kinyert léptető és DC motorok, mivel ezek nem rendelkeztek vezetékkel.

\section{PROCESSING IDE ALKALMAZÁSA}

A Processing egy nyílt forráskódú grafikus programozási nyelv, valamint a hozzá tartozó integrált fejlesztői környezet (IDE). A nyelv maga a Java alapjait alkalmazza, Mivel az Arduino IDE és a Processsing IDE is Java nyelvre támaszkodik, így ugyanúgy platform független, illetve bizonyos szintü átjárás lehetséges a két fejlesztői környezett között. [5].

Külön kiemelendő, hogy az IDE -ben való programozást Linux Manjaro disztribúció alatt került elvégzésre [8].

Ennek a programnak a segítségével leolvashatjuk a kiválasztott kép pixeleit, és soros porton keresztül továbbíthatjuk a mikrokontroller számára, ami ez után vezérli a motorokat, úgy, hogy a nyomtató a kívánt képet a papírra vigye.

A megírt program könnyen használható, mindössze két sor változtatásával máris új kép nyomtatható.

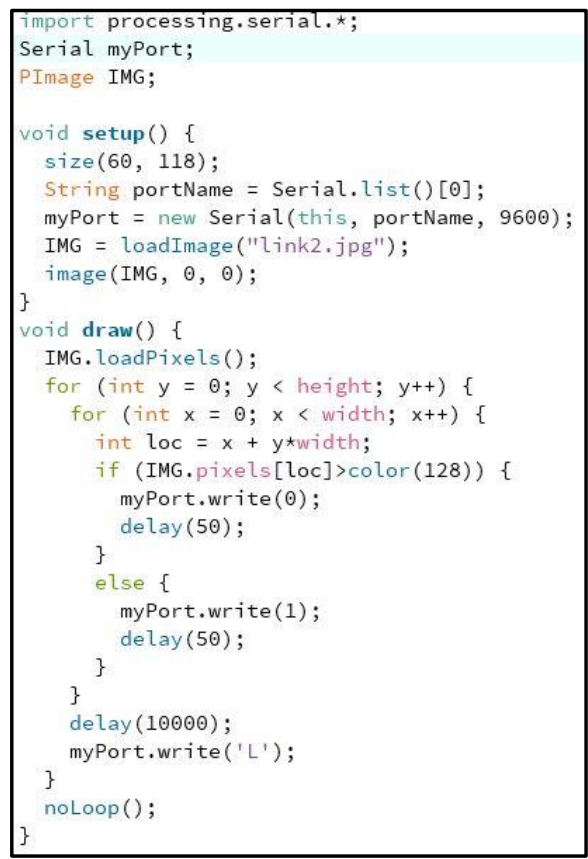

4. ábra : Processing program részlet I.

Ehhez annyi szükséges, hogy a size(); utasítás kerek zárójel párja közé a kívánt kép méretét írjuk, szélesség $\mathrm{x}$ magasság arányban. Ezen kívül már csak a loadImage(,”); utasítás idézőjelei közé kell elhelyezni a fájl nevét, és annak kiterjesztését.

\section{ARDUINO POROGRAMOZÁSA}

$\mathrm{Az}$ Arduino programozása a saját, ingyenesen elérhető (1.8.5. verzió számú) integrált fejlesztői környezetben történt.

A program a Processingtől kapott információk alapján dönti el, hogy az adott pozícióban a tollnak szükséges- e pontot elhelyezni.

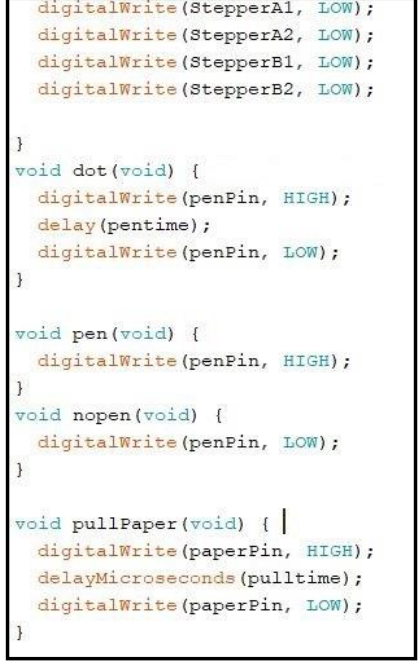

5. ábra : Processing program részlet II.

Amennyiben igen, úgy a vízszintes irányban mozgó tollat vezérlő motor müködésbe lép, ha viszont nem, akkor a léptető motor a következő pozícióba mozog. Ha ezen a helyen eléri a sor végét, akkor a papír mozgását végző motor új sorba lépteti, és a toll ennek a sornak az elejére tér vissza.

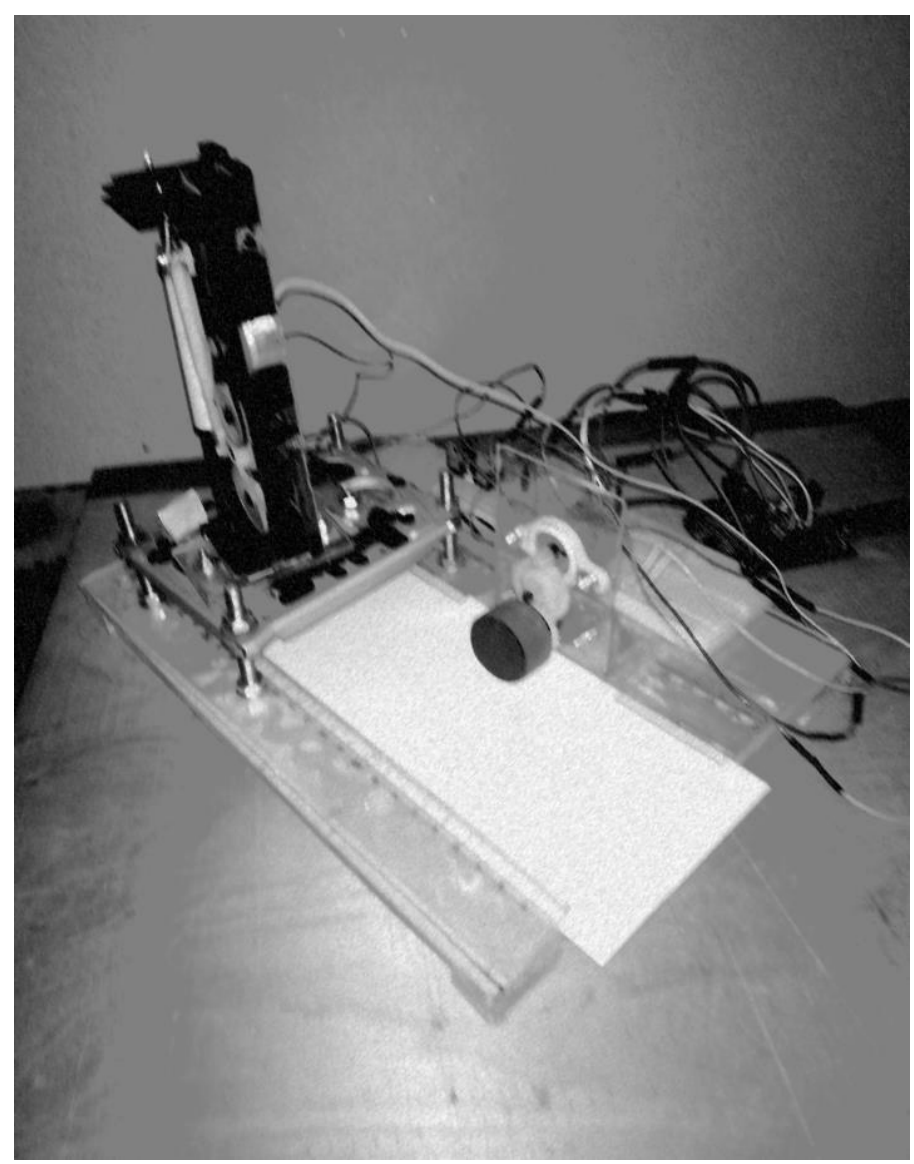

5. ábra : Megtervezett \& vezérelt pontmátrix nyomtató 


\section{VII. ÖSZEGZÉS}

A pontmátrix nyomtató néhány könnyen beszerezhető elektronikai alkatrész, illetve egy mikrokontrolleren kívül otthoni háztartásban is megtalálható alkatrészekből készült el. A papír szélessége maximálisan 9,2 cm, viszont a legnagyobb nyomtatható kép szélessége nem haladja meg az 5,2 cm-t.

Hátrányként megemlíthető, hogy a nyomtatás sebessége lassú, ezért egy-egy kép megalkotása időigényes lehet, az adott feladat függvényében.

Fejlesztési lehetőségként a léptető motor tartó szerkezet méretének növelésével a nyomtató akár nagyobb képek kinyomtatására is képes lehet. Ezen felül egy újabb filctoll mozgatását végző motor hozzáadásával egyszerre akár két színt használhatunk.

\section{KÖSZÖNETNYÍLVÁNÍTÁS}

A publikáció elkészítését az EFOP-3.6.1-16-2016-00022 számú projekt támogatta. A projekt az Európai Unió támogatásával, az Európai Szociális Alap társfinanszírozásával valósult meg.

\section{HIVATKOZÁSOK}

[1] Story and History of Develpment of Arduino (2018, Május 15.) [Online] Available: $\quad$ http://www.circuitstoday.com/story-and-history-ofdevelopment-of-arduino

[2] Arduino nano (2018, Május 15.) [Online] Available: https://store.arduino.cc/arduino-uno-rev3

[3] L293D motorvezérlő, (2018, Május 16). [Online]. Avalable: http://www.instructables.com/id/L293D-Motor-Driver/

[4] Fritzing, (2018.05.18). [Online]. Available: http://fritzing.org/home/

[5] Processing, (2018. május 18). [Online]. Available: https://processing.org/

[6] History of printing, (2018. május 18). [Online]. Available: http://www.historyworld.net/wrldhis/PlainTextHistories.asp?historyid=a b78

[7] Epson T1000 model, (2018. május 18). [Online]. Available: https://www.manualslib.com/manual/237752/Epson-Stylus-T-1000.html

[8] Linux Manjaro, (2018. május 18). [Online]. Available: https://manjaro.org/

[9] T. I. Erdei, Zs. Molnár, N. C. Obinna, G. Husi, „Cyber physical systems in mechatronic research centre," MATEC Web Conf. Volume 126, 2017 